\title{
Contribution of seed traits to the genetic diversity of a segregating population of Passiflora spp.
}

\author{
Géssica Xavier Torres ${ }^{1}$, Alexandre Pio Viana ${ }^{1}$, Henrique Duarte Vieira ${ }^{1}$, Daniele Lima Rodrigues ${ }^{1 *}$, \\ and Valquíria Oliveira dos Santos ${ }^{1}$
}

'Universidade Estadual do Norte Fluminense Darcy Ribeiro, Centro de Ciências e Tecnologias Agropecuárias, Avenida Alberto
Lamego, 2000, Parque Califórnia, 28013-602, Campos dos Goytacazes, Rio de Janeiro, Brasil.
"Corresponding author (danilr.daniele@gmail.com).

Received: 14 August 2018; Accepted: 11 January 2019; doi:10.4067/S0718-58392019000200288

\begin{abstract}
Genetic diversity can be investigated early using seed traits, an important aspect of sexually propagated species. In this context, plant breeders aim at the production of new varieties using seeds with good germination and vigor. The present study was thus designed to examine the genetic diversity of a segregating population from a cross between Passiflora edulis Sims and P. setacea DC. based on seed morphological- and physiological-quality responses. Seventeen seed morphology variables were evaluated via digital image analysis, and a germination test and four vigor tests were applied for the evaluation of physiological quality. Data were interpreted by multivariate analysis for the evaluation of genetic diversity. The parents were allocated to distinct groups by the dendrogram structured using Euclidean distance, based on the morphological- and physiological-quality traits. The unweighted pair group method using arithmetic averages (UPGMA) clustering method formed three groups, the first one represented by backcrossing 32, the second by P. setacea and the third by a larger number of genotypes (P.edulis, hybrids and other backcrosses). The principal component analysis showed that the first two components explained $61.32 \%$ of the variation. The clustering methods were efficient in the evaluation of dissimilarity of genotypes from a segregating population of Passiflora.
\end{abstract}

Key words: Backcrossing, genetic variability, hybrids, Passiflora edulis, Passiflora setacea.

\section{INTRODUCTION}

In passionfruit (Passiflora edulis Sims) growing, improper management and lack of cultivars with good agronomic characteristics that are also resistant to diseases and pathogens culminate in low yields (Silva et al., 2014). Therefore, perfecting works devoted to the breeding of this crop is a measure of paramount importance, especially when it comes to disease susceptibility. Some studies have been carried out for the development of resistance to the passionfruit woodiness disease caused by the Cowpea aphid-borne mosaic virus (CABMV), whose symptoms range from a leaf mosaic to leaf deformation, affecting photoassimilate production by the plants, besides other symptoms such as slow growth, shortening of the internodes, and production of smaller and hardened fruits (Maciel et al., 2009; Monteiro-Hara et al., 2011; Santos et al., 2014; Freitas et al., 2016).

Passiflora edulis (sour passionfruit) is a species of commercial interest. It is susceptible to the CABMV, which contributes to the decimation of several orchards in Brazil. Crossing it with P. setacea, a species resistant to the virus, is an alternative for its control, which is obtained through the introgression of genes that provide resistance (Santos et al., 2014; Freitas et al., 2016).

Information about the genetic divergence of a population is essential in any breeding program, since it aids in the differentiation of accessions, identification of contrasting genotypes, and making of future crosses, thereby providing a database for the identification of possible groups with a higher degree of heterosis (Silva et al., 2014). 
At commercial level, passionfruit is propagated via seeds, which demonstrates the importance of evaluating the contribution of their attributes in the genetic breeding of this crop (Meletti, 2011). Characteristics correlated with the physiological quality of seeds are known to be generally inherited from their parents; therefore, different varieties of one species may show variations in vigor, germination, and field emergence (Mertz et al., 2009). In the development of new cultivars with resistance and good agronomic attributes, breeders should take the seed-related variables into consideration, since new cultivars with good germination capacity are highly desired.

Principal component analysis is a multivariate technique whose purpose is to describe the data contained in an individuals-numerical variables interface, where $\mathrm{p}$ variables will be measured in $\mathrm{n}$ individuals. This is considered a factorial method, since the number of variables is reduced by constructing new synthetic variables, which are obtained by the linear combination of the initial variables, through the factors (Bouroche and Saporta, 1982). The use of clustering methods, whose application depends on the utilization of a previously estimated dissimilarity measure, is employed to propose a structure for the recognition of the existence of homogeneous groups, which makes it possible to determine which traits contribute to diversity in a population (Cruz et al., 2012).

Paiva et al. (2014) investigated genetic diversity in wild species and commercial varieties of Passiflora species using qualitative and quantitative morphological traits and by employing Ward's Modified Location Model (MLM) statistical method, which revealed wide genetic diversity between the studied Passiflora species. Santos et al. (2014) identified three groups by distinctly separating genotypes of $P$. edulis and $P$. setace $a$ and the hybrids between these two species using the same statistical method.

The present study proposed to examine the genetic diversity of a segregating population from the cross between $P$. edulis and P. setacea based on responses in physiological quality and variables obtained by digital seed phenotyping.

\section{MATERIALS AND METHODS}

The experiment was conducted at the Laboratory of Plant Science of the Seed Technology Unit at the Universidade Estadual do Norte Fluminense Darcy Ribeiro (UENF), Campos dos Goytacazes, Rio de Janeiro, Brazil. The seeds originated from the passionfruit breeding program aimed at resistance to the Cowpea aphid-borne mosaic virus (CABMV) developed at the Laboratory of Plant Genetics and Breeding at UENF. For the extraction of the seeds, we used ripe fruits of Passiflora edulis (1), P. setacea (1), interspecific hybrids (10), and backcrossed individuals (25), whose recurrent parent was $P$. edulis, totaling 37 genotypes (Table 1).

The seeds were extracted by rubbing on a steel-mesh sieve under running water to remove the mucilage. Afterwards, they were placed on paper towels to be dried at room temperature for $48 \mathrm{~h}$. After drying, the tests for evaluation of the physical, morphological, and physiological quality of the seeds were undertaken.

For the germination test, seeds were placed between two sheets of Germitest paper (CIENLAB Equipamentos Científicos, Campinas, São Paulo, Brazil) moistened with distilled water at the rate of 2.5 times their weight. Next, they were taken to chambers regulated at an alternated temperature of $20-30{ }^{\circ} \mathrm{C}$, with $8 \mathrm{~h} \mathrm{light}(150 \mathrm{~W}$ power) supplied at the highest temperature and remained in dark for $16 \mathrm{~h}$ at the lowest temperature. The first assessment took place at $14 \mathrm{~d}$, and the last one at $28 \mathrm{~d}$, on which occasions the percentage of normal seedlings was recorded (adapted from Brasil, 2009).

The following tests were performed for the evaluation of seed vigor: first germination count, percentage of normal seedlings in the first count of the germination test (Krzyzanowski et al., 1999; Brasil, 2009); seedling length by measuring the 10 seedlings located in the upper row of the paper rolls from the germination test; radicle length by measuring the radicles of the 10 seedlings located in the upper row of the paper rolls from the germination test (Negreiros et al., 2008); and radicle emission speed index by counting seeds that produced a radicle up to the $28^{\text {th }}$ day, performed every $2 \mathrm{~d}$ (Maguire, 1962).

The GroundEye Mini 180 (2014 Tbit Systems and Technology, Lavras, Minas Gerais, Brazil) equipment provides data on size and seed color, seedling measurement to determine the vigor and size of the structures of each seedling, among others data and generated a spreadsheet with the mean values of the analyzed variables for each genotype. In this study, 342 variables were obtained, 107 of which remained after a screening procedure. Of these 107 variables, 37 pertained to color, 41 to geometry, and 29 to texture. The screening consisted of excluding qualitative variables; histogram variables, which are a graphical representation of the frequency distribution of a mass of measurements; and variables for which all 
Table 1. Passiflora edulis and P. setacea genotypes, interspecific hybrids (IH), and backcrossed individuals (BC) used in the study of genetic diversity based on attributes of seeds and their respective origins. Universidade Estadual do Norte Fluminense (UENF), Campos dos Goytacazes, 2018.

\begin{tabular}{|c|c|}
\hline Genotypes & Genitors $(\varphi \times \overbrace{}^{\pi})$ \\
\hline Passiflora edulis & UENF Rio Dourado* \\
\hline P. setacea & UENF germplasm bank \\
\hline H1 & P. setacea $367 \times$ P. edulis 139 (40) \\
\hline $\mathrm{H} 2$ & P. setacea $367 \times$ P. edulis $139(40)$ \\
\hline $\mathrm{H} 3$ & P. setacea $367 \times$ P. edulis $139(40)$ \\
\hline H5 & P. setacea $367 \times$ P.edulis $139(40)$ \\
\hline $\mathrm{H} 7$ & P. setacea $367 \times$ P. edulis $139(40)$ \\
\hline H11 & P. setacea $367 \times$ P. edulis $139(40)$ \\
\hline H12 & P. setacea $367 \times$ P. edulis $139(40)$ \\
\hline H13 & P. setacea $367 \times$ P. edulis $139(40)$ \\
\hline H14 & P. edulis $139(40) \times$ P. setacea 367 \\
\hline H15 & P. edulis $139(40) \times$ P. setacea 367 \\
\hline $\mathrm{BC} 3$ & IH 5-14 × P. edulis* \\
\hline $\mathrm{BC} 10$ & IH 5-14 × P. edulis* \\
\hline BC16 & IH 5-16 × P. edulis* \\
\hline BC18 & IH 5-16 × P. edulis* \\
\hline BC24 & IH 5-16 × P. edulis* \\
\hline BC26 & IH 5-16 × P. edulis* \\
\hline BC32 & IH 5-14 × P. edulis* \\
\hline BC35 & IH 5-14 × P. edulis* \\
\hline BC37 & IH 5-14 × P. edulis* \\
\hline BC38 & IH $1-15 \times$ P. edulis* \\
\hline BC44 & IH 5-16 × P. edulis* \\
\hline BC47 & IH 5-1 $\times$ P. edulis* \\
\hline BC48 & IH 5-1 $\times$ P. edulis* \\
\hline BC50 & IH 2-10 × P. edulis* \\
\hline BC51 & IH 5-14 × P. edulis* \\
\hline BC53 & IH 5-14 × P. edulis* \\
\hline BC57 & IH 1-15 × P. edulis* \\
\hline ВC59 & IH 5-16 × P. edulis* \\
\hline BC61 & IH 5-16 × P. edulis* \\
\hline BC62 & IH 5-16 × P. edulis* \\
\hline BC66 & IH 5-16 × P. edulis* \\
\hline BC71 & IH 5-14 × P. edulis* \\
\hline BC80 & IH 1-15 × P. edulis* \\
\hline ВC83 & IH 5-16 $\times$ P. edulis* \\
\hline ВС92 & IH 5-1 $\times$ P. edulis* \\
\hline
\end{tabular}

*Cultivar from the recurrent selection program of UENF registered at the Brazilian Ministry of Agriculture, Livestock, and Food Supply (MAPA).

values obtained in each genotype were equal, i.e., which did not contribute to the evaluation of diversity. The contribution of each variable to the importance of traits was shown by the generalized Mahalanobis distance method. Geometry and texture variables underwent data transformation through the expression $\sqrt{ } x+0.5$, since they did not have normal distribution. Based on the importance of traits, the variables that contributed with values greater than $5 \%$ were selected to determine the composition of the groups for the study of genetic diversity.

The morphological- and physiological-quality variables were used in multivariate analysis and in the unweighted pair group method using arithmetic averages (UPGMA) hierarchical clustering method, which revealed the contribution of each variable to the importance of the traits based on generalized Mahalanobis distance. Subsequently, a dendrogram was constructed using Euclidian distance, by the UPGMA clustering method, to identify the genetic diversity of the population. 


\section{RESULTS AND DISCUSSION}

For the evaluation of divergence, seed color, geometry, and texture variables that contributed with more than 5\% to the importance of traits in each isolated group were selected (Table 2). In this way, we selected those that most contributed to the analysis, since the GroundEye equipment provides a high number of variables.

Seventeen seed color, geometry, and texture variables that contributed with more than 5\% to the importance of traits of each individual group were thus used; color variables below the Otsu threshold: CIELab a, CIELab dispersion, CIELab dispersion of L, and CIELab L, black dominance, hue variance; geometric variables: Feret diameter, number of Harris corners, medium area, larger area, smaller area, and elliptical variation; texture variables: Haralick contrast, Haralick dissimilarity, RunLength HGRE (high gray-level run emphasis), RunLength LRHGE (long-run, high gray-level emphasis) and RunLength SRHGE (short-run, high gray-level emphasis) (Xu et al., 2004).

After the 17 variables were selected, they were joined with the seed physiological-quality traits for the evaluation of diversity between the genotypes. The seed texture variables Run Length: HGRE and Run Length: SRHGE were those that most contributed to the diversity of the genotypes, with $76.28 \%$ (Table 3 ).

The physiological-quality variables contributed only with a total of $3.25 \%$, which shows that they were not the most suitable to determine the genetic diversity of the population, in this study.

The UPGMA clustering method resulted in three groups formed with the 37 genotypes of Passiflora spp. tested in this study, using the 22 variables related to seed physiological and morphological quality. The first group was represented by $\mathrm{BC} 32$; the second, by Ps; and the third, by a higher number of genotypes, namely Pe, hybrids, and other backcrosses (Figure 1). This representation clearly demonstrates the separation of the parentals Pe and Ps; i.e., according to the dissimilarity of the data, they have larger distances between groups.

The dendrogram shows that the parentals Pe and Ps were allocated to distinct groups, as they are agronomically different and contrasting, mainly in terms of germination and seed vigor. The wild species $P$. setacea presents low and irregular germination, whereas $P$. edulis has a high germination rate.

Orozco-Restrepo et al. (2014) observed low germination (> 7\%) in P. setacea seeds obtained from natural pollination, self-pollination, and a cross between flowers of different plants, proving the low germination rate of this species. Passiflora

Table 2. Estimates of the relative contribution of each trait $\left(S_{j}\right)$ of color, geometry, and texture traits for genetic diversity by generalized Mahalanobis distance with percentage values above $5 \%$ in each isolated group of traits.

\begin{tabular}{|c|c|c|}
\hline Variable & $\mathrm{S}_{\mathrm{j}}$ & $\%$ Value \\
\hline \multicolumn{3}{|c|}{ Color character group } \\
\hline Below the Otsu: CIELab: a & 76474.00 & 6.14 \\
\hline CIELab: Dispersion & 167245.30 & 13.44 \\
\hline CIELab: Dispersion of $\mathrm{L}$ & 149563.00 & 12.02 \\
\hline CIELab: L & 182800.51 & 14.69 \\
\hline Black dominance & 63768.16 & 5.12 \\
\hline Hue variance & 63428.83 & 5.09 \\
\hline \multicolumn{3}{|c|}{ Geometry character group } \\
\hline Feret diameter & 30101.07 & 5.65 \\
\hline Number of Harris corners & 58495.06 & 10.98 \\
\hline Circumscribed rectangles: medium area & 31721.41 & 5.95 \\
\hline Circumscribed rectangles: larger area & 32091.53 & 6.02 \\
\hline Circumscribed rectangles: smaller area & 29047.99 & 5.45 \\
\hline Elliptical variation & 28198.70 & 5.29 \\
\hline \multicolumn{3}{|c|}{ Texture character group } \\
\hline Haralick: Contrast & 74489.59 & 5.02 \\
\hline Haralick: Dissimilarity & 160229.72 & 10.80 \\
\hline Run Length: HGRE** & 359424.27 & 24.23 \\
\hline Run Length: LRHGE* & 95531.82 & 6.44 \\
\hline Run Length: SRHGE* & 431137.87 & 29.06 \\
\hline
\end{tabular}

*HGRE: High gray-level run emphasis; LRHGE: long-run, high gray-level emphasis; SRHGE: short-run, high gray-level emphasis. 
Table 3. Estimates of the relative contribution of each trait $\left(S_{j}\right)$ to genetic divergence for seed morphological- and physiological-quality variables in $\mathbf{3 7}$ genotypes of a segregating population of Passiflora.

\begin{tabular}{lcc}
\hline Variable & \multicolumn{1}{c}{$\mathrm{S}_{\mathrm{j}}$} & \% Value \\
\hline First count & 22715.63 & 1.09 \\
Germination & 21624.41 & 1.04 \\
Seedling length & 5045.234 & 0.24 \\
Radicle length & 15040.44 & 0.72 \\
Radicle emission speed index & 3310.78 & 0.16 \\
Below the Otsu: CIELab: a & 42764.34 & 2.06 \\
CIELab: Dispersion & 641.86 & 0.03 \\
CIELab: Dispersion de L & 13450.70 & 0.65 \\
CIELab: L & 60369.52 & 2.90 \\
Black dominance & 26980.65 & 1.30 \\
Hue variance & 61422.839 & 2.96 \\
Feret diameter & 10349.989 & 0.50 \\
Number of Harris corners & 18746.159 & 0.90 \\
Circumscribed rectangles: medium area & 11897.149 & 0.57 \\
Circumscribed rectangles: larger area & 4826.79 & 0.23 \\
Circumscribed rectangles: smaller area & 10514.43 & 0.51 \\
Elliptical variation & 51277.07 & 2.47 \\
Haralick: Contrast & 29093.04 & 1.40 \\
Haralick: Dissimilarity & 79329.20 & 3.82 \\
Run Length: HGRE & 821505.41 & 39.52 \\
Run Length: LRHGE & 3557.09 & 0.17 \\
Run Length: SRHGE & 764177.92 & 36.76 \\
\hline
\end{tabular}

*HGRE: High gray-level run emphasis; LRHGE: long-run, high gray-level emphasis; SRHGE: short-run, high gray-level emphasis.

edulis, in turn, has a high germination rate, as demonstrated in the study of Santos et al. (2015), who obtained percentages higher than $90 \%$ in seven genotypes in open and self-pollination, which were carried out in the bud stage aiming to overcome self-incompatibility.

In the case of hybrids from passionfruit progeny, the germination percentage ranged from $3 \%$ to $84 \%$ (Souto et al., 2017).

Genotype BC32 obtained a germination rate of $85 \%$, and was thus not too distant from genotype Pe (95\%). The same was found in the vigor tests. However, the divergence between this genotype and the others may be explained in the analysis of images by the texture variables RunLength: HGRE and RunLength: SRHGE, which, together, contributed with 76\% to the importance of traits and responded with differences in the means between genotypes Pe and $\mathrm{BC} 32$ (35.7\% and $36.7 \%$, respectively). Nevertheless, in a study of diversity of guava progeny through digital seed phenotyping, the variables that most contributed to divergence between the genotypes were the seed geometry traits (Krause et al., 2017).

Cerqueira-Silva et al. (2009) evaluated intra- and interspecific genetic dissimilarity between genotypes of P. edulis and $P$. setacea via physicochemical descriptors - interspecifically, mainly - and found variability between the genotypes.

Rodrigues et al. (2017) also observed groups of passionfruit progeny formed by the UPGMA method at three fertilization levels, in an evaluation of seed and yield variables. The progeny were clustered distinctly at the different fertilization levels, and the variables seedling length and germination speed index were positively correlated with number of fruits, pulp weight, and fruit weight in lower nutrient-availability conditions.

In a digital analysis of seeds, Krause et al. (2017) reported efficient quantification of diversity between genotypes of inbred guava (Psidium guajava L.) families and concluded that image analysis using the GroundEye system was efficient for the genotypes of guava families when associated with the Ward-MLM method.

In the present experiment, principal component analysis (PCA) showed that the first two components explained 61.32\% of the variation, $40.44 \%$ of which were given by PC1 and $20.88 \%$ by PC2 (Figure 2). A two-dimensional graph thus represented the proportion of total variability, showing the distance between groups seen in Figure 1, where P. setacea and $\mathrm{BC} 32$ were far from the largest group, represented by P. edulis, the hybrids, and the other backcrosses. 
Figure 1. Dendrogram of genetic dissimilarities between 37 passionfruit genotypes based on 22 seed physiological- and morphological-quality traits obtained using Euclidean distance and the unweighted pair group method using arithmetic averages (UPGMA) clustering method.

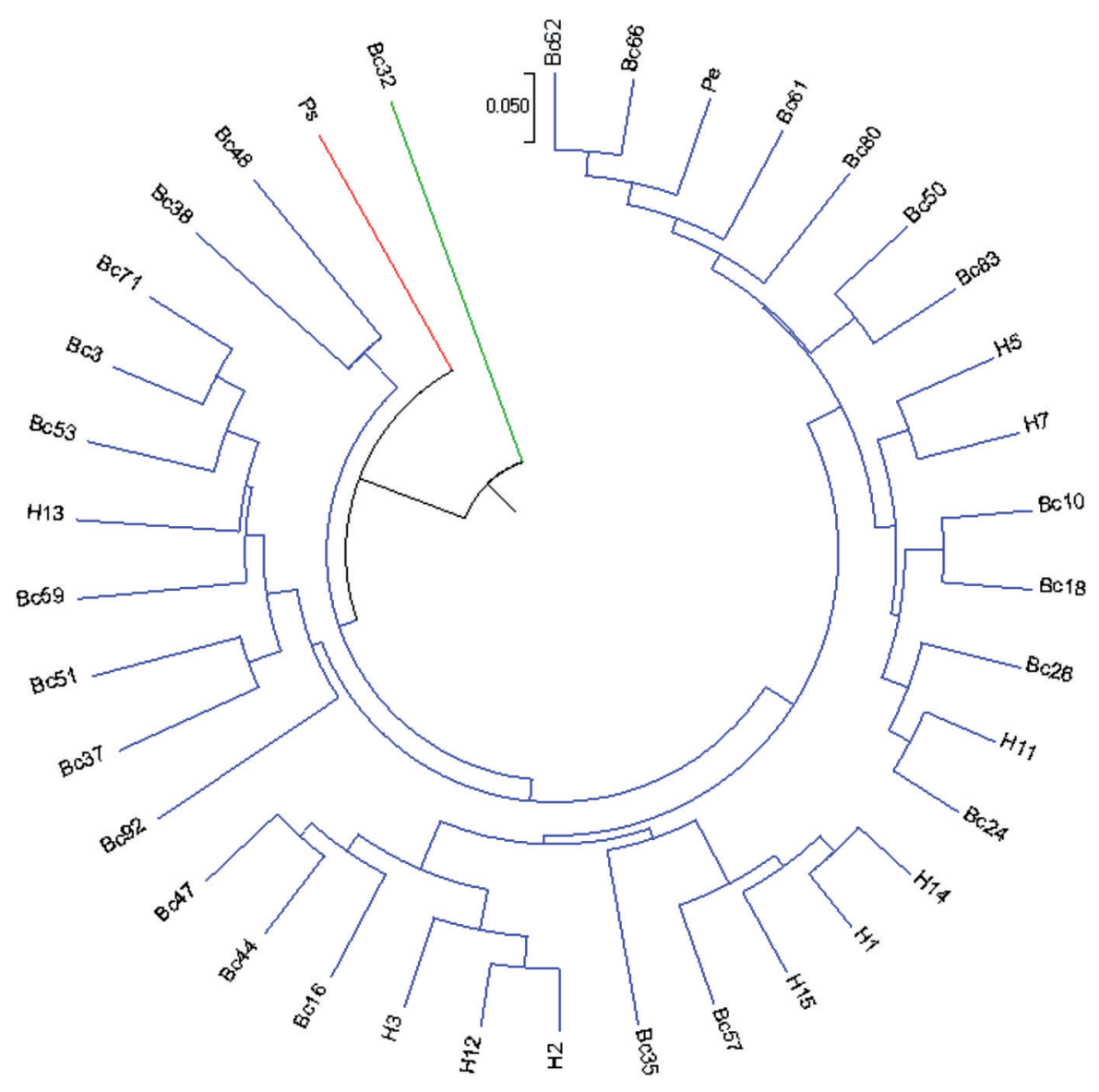

Crochemore et al. (2003) observed separation of groups across diverse species of Passiflora spp. according to 22 agromorphological descriptors. Silva et al. (2014) identified the distancing of groups formed by Ward-MLM analysis of 81 full-sib progeny of passionfruit using qualitative and quantitative descriptors of leaf, flower, and fruit.

A study on the genetic diversity of 11 species of the genus Passiflora by the Ward-MLM method clearly demonstrated how the different groups formed were clustered in a two-dimensional graphical dispersion (Paiva et al., 2014).

After phenotyping $P$. edulis and P. setacea genotypes and their resulting hybrids through qualitative and quantitative analysis of leaf, flower, and fruit, Santos et al. (2014) formed three groups. Each group contained a set of similar genotypes: group I included hybrids; group II contained P. setacea genotypes; and group III contained P. edulis genotypes. However, in the evaluation of seed morphological and physiological traits, although the parents were present in different groups, the hybrids were allocated in the same group as the parent $P$. edulis. The hybrids responded with germination and vigor values lower than those shown by P. edulis, but exhibited similar values for the texture variables RunLength: HGRE and RunLength: SRHGE, which were the most significant in the formation of the groups. Therefore, genetic diversity can be evaluated earlier and faster using seed traits. 
Figure 2. Distribution of the genotypes from a segregating population of Passiflora spp. H (Hybrid), Pe (Passiflora edulis), Ps (Passiflora setaceae), Bc (Backcrossing) and Bc 32 (Backcross genotype 32).

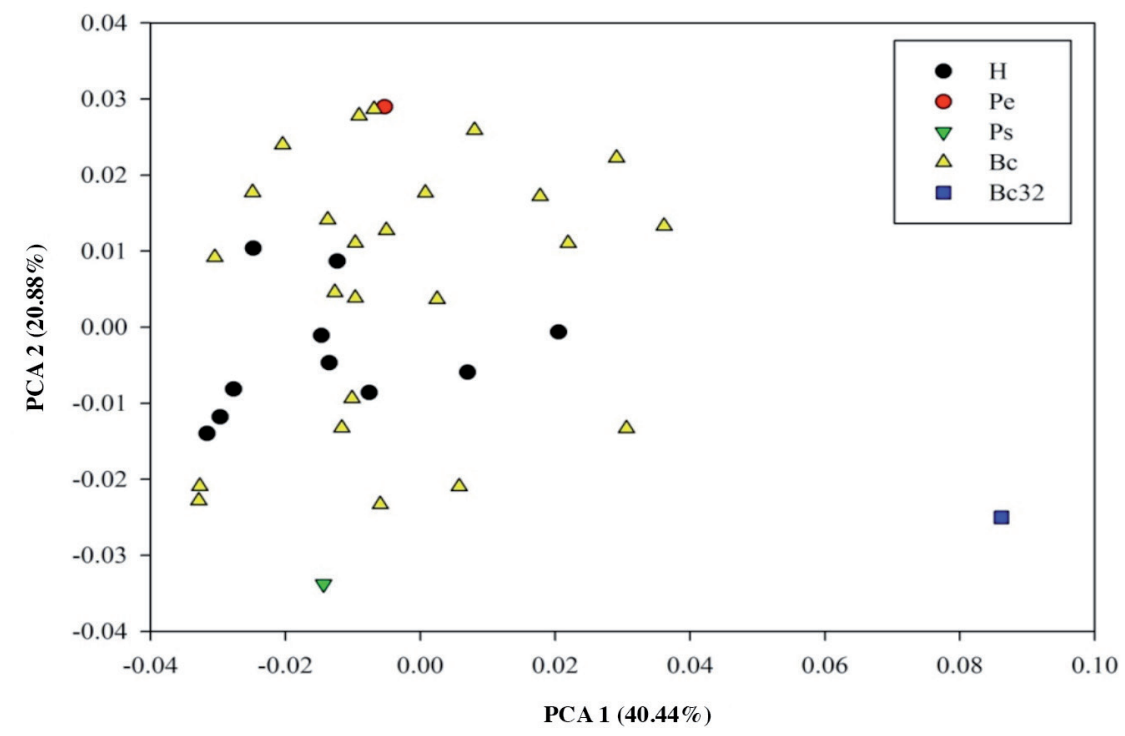

\section{CONCLUSIONS}

Parentals were separated by the dendrogram structured based on Euclidean distance, based on the germination and vigor variables added to the digital-phenotypic variables. The hybrids and most part of the backcrosses were clustered together with the parent Passiflora edulis.

The clustering methods were efficient in the evaluation of the dissimilarity index of passionfruit genotypes via seed traits.

\section{REFERENCES}

Bouroche, J.M., e Saporta, G. 1982. Análise de dados. 117 p. Zahar, Rio de Janeiro, Brasil.

Brasil. 2009. Ministério da Agricultura, Pecuária e Abastecimento: Regras para análise de sementes. 395 p. Ministério da Agricultura, Pecuária e Abastecimento (MAPA/ACS), Secretaria de Defesa Agropecuária, Brasília, Brasil.

Cerqueira-Silva, C.B.M., Cardoso-Silva, C.B., Notato, J.V.A., Corrêa, R.X., and Oliveira, A.C. 2009. Genetic dissimilarity of 'yellow' and 'sleep' passion fruit accessions based on the fruits' physical chemical characteristics. Crop Breeding and Applied Biotechnology 9:210-218. http://www,sbmp,org,br/cbab/siscbab/uploads/c8eb9791-1c50-eaa6,pdf.

Crochemore, M.L., Molinari, H.B., e Stenzel, N.M.C. 2003. Caracterização agromorfológica do maracujazeiro (Passiflora spp.) Revista Brasileira de Fruticultura 25(1):5-10. https://dx,doi,org/10,1590/S0100-29452003000100004.

Cruz, C.D., Regazzi, A.J., e Carneiro, P.C.S.C. 2012. Modelos biométricos aplicados ao melhoramento genético. 4 ed. 514 p. Editora UFV, Viçosa, Minas Gerais, Brasil.

Freitas, J.C.O., Viana, A.P., Santos, E.A., Paiva, C.L., Silva, F.H.L.E., and Souza, M.M. 2016. Sour passion breeding: Strategy applied to individual selection in segregation population of Passiflora resistant to Cowpea aphid-born mosaic virus (CABMV). Scientia Horticulturae 211:241-247. https://doi.org/10.1016/j.scienta.2016.09.002.

Krause, W., Viana, A.P., Cavalcante, N.R., Ambrósio. M., Santos, E.A., and Vieira, H.D. 2017. Digital phenotyping for quantification of genetic diversity in inbred guava (Psidium guajava) families. Genetic and Molecular Research 16(1):gmr16019474. http://dx.doi.org/10.4238/gmr16019474.

Krzyzanowski, F.C., Vieira, R.D., e França-Neto, J.B. (eds.) 1999. Vigor de sementes: conceitos e testes. p. 1-24. Abrates, Londrina, Paraná, Brasil.

Maciel, S.C., Nakano, D.H., Rezende, J.A.M., and Vieira, M.L.C. 2009. Screening of Passiflora species for reaction to Cowpea aphid-borne mosaic virus reveals an immune wild species. Scientia Agricola 66(3):414418. doi:10,1590/S0103-90162009000300018. 
Maguire, J.D. 1962. Speed of germination-aid in selection and evaluation for seedling emergence and vigor. Crop Science 2(1):176-177.

Meletti, L.M.M. 2011. Avanços na cultura do maracujá no Brasil. Revista Brasileira de Fruticultura 33(spe1):83-91. https://dx,doi,org/10,1590/S0100-29452011000500012.

Mertz, L.M., Henning, F.A., Cruz, H.L., Meneghello, G.E., Ferrari, C.S., e Zimmer, P.D. 2009. Diferenças estruturais entre tegumentos de sementes de soja com permeabilidade contrastante. Revista Brasileira de Sementes 31(1):23-29. http://dx.doi.org/10.1590/S0101-31222009000100003.

Monteiro-Hara, A.C.B.A., Jadão, A.S., Mendes, B.M.J., Rezende, J.A.M., Mello, A.P.O.A., Meletti, L.M.M., et al. 2011 . Genetic transformation of passion flower and evaluation of $\mathrm{R}_{1}$ and $\mathrm{R}_{2}$ generations for resistance to Cowpea aphid borne mosaic virus. Plant Disease 95(8):1021-1025. https://doi,org/10,1094/PDIS-12-10-0873.

Negreiros, J.R.S., Alexandre, R.S., Álvares, V.S., Bruckner, C.H., e Cruz, C.D. 2008. Divergência genética entre progênies de maracujazeiro amarelo, com base em características das plântulas. Revista Brasileira de Fruticultura 30(1): 197-201. http://dx.doi.org/10.1590/S0100-29452008000100036.

Orozco-Restrepo, S.M., Rojas-Duque, S.L., Santos, T.M., Aristizábal-Loaiza, J.C., y Horst-Bruckner, C. 2014. Evaluación de fructificación y determinación de la capacidad germinativa de semillas en Passiflora setacea. Revista Agronomía 22(1):66-76.

Paiva, C.L., Viana, A.P., Santos, E.A., Silva, R.N.O., e Oliveira, E.J. 2014. Diversidade genética de espécies do gênero Passiflora com o uso da estratégia Ward-MLM. Revista Brasileira de Fruticultura 36(2):381-390. https://dx,doi,org/10,1590/0100-2945-156/13.

Rodrigues, D.L., Viana, A.P., Vieira, H.D., Santos, E.A., Silva, F.H.L., and Santos, C.L. 2017. Contribution of production and seed variables to the genetic divergence in passion fruit under different nutrient availabilities. Pesquisa Agropecuária Brasileira, Brasília 52(8):607-614. http://dx.doi.org/10.1590/s0100-204x2017000800006.

Santos, C.E.M., Morgado, M.A.D.O., Matias, R.G.P., Wagner Júnior, A., and Bruckner, C.H. 2015. Germination and emergence of passion fruit (Passiflora edulis) seeds obtained by self- and open-pollination. Acta Scientiarum, Agronomy 37(4):489493. http://dx,doi,org/10,4025/actasciagron,v37i4,19616.

Santos, E.A., Viana, A.P., Freitas, J.C.O., Souza, M.M., Paiva, C.L., Rodrigues, D.L., et al. 2014. Phenotyping of Passiflora edulis, P. setacea, their hybrids by a multivariate approach. Genetics and Molecular Research 13(4):98289845. http://dx,doi,org/10,4238/2014,November,27,10.

Silva, F.H.L., Viana, A.P., Ferreira, R.T., Freitas, J.C.O., Santos, J.O., and Rodrigues, D.L. 2014. Measurement of genetic diversity in progenies of sour passion fruit by ward-MLM methodology: a strategy for heterotic group formation. Ciência e Agrotecnologia 38(3):240-246. https://dx,doi,org/10,1590/S1413-70542014000300003.

Souto, A.G.L., Cremasco, J.P.G., Maitan, M.Q., Azevedo, J.L.F., Ribeiro, and M.R., Santos, C.E.M. 2017. Seed germination and vigor of passion fruit hybrids. Comunicata Scientiae 8(1):134-138. https://doi,org/10,14295/cs,v8i1,1379.

Xu, D., Kurani, A.S., Furst, J.D., and Raicu, D.S. 2004. Run-length encoding for volumetric texture. The $4^{\text {th }}$ IASTED International Conference on Visualization, Imaging, and Image Processing, Marbella. 6-8 September. International Association of Science and Technology for Development (IASTED), Calgary, Canada. 